
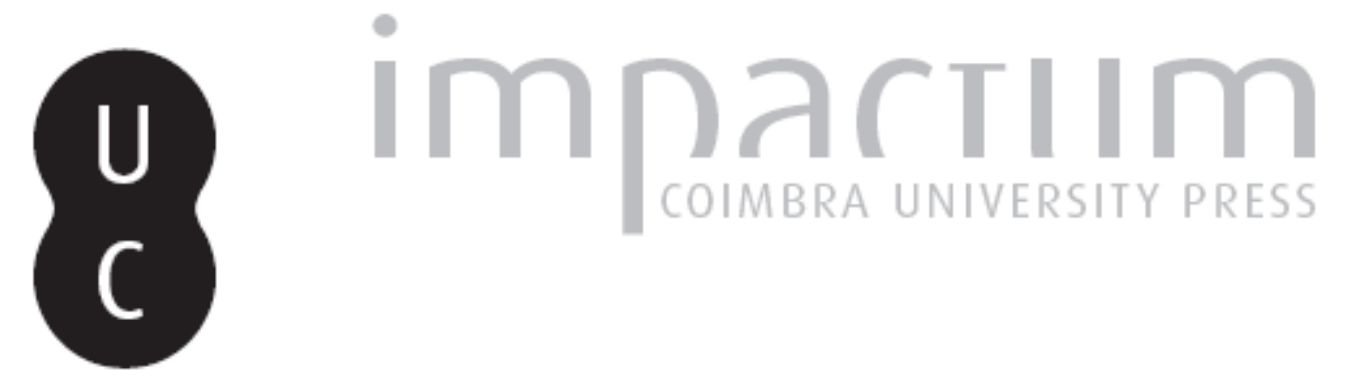

Ao longo do Tejo, do bronze ao ferro

Autor(es): $\quad$ Vilaça, Raquel; Arruda, Ana Margarida

Publicado por: Faculdade de Letras da Universidade de Coimbra

URL persistente:

URI:http://hdl.handle.net/10316.2/37699

DOI:

DOI:http://dx.doi.org/10.14195/1647-8657_43_1

Accessed : $\quad$ 26-Apr-2023 12:25:26

A navegação consulta e descarregamento dos títulos inseridos nas Bibliotecas Digitais UC Digitalis, UC Pombalina e UC Impactum, pressupõem a aceitação plena e sem reservas dos Termos e Condições de Uso destas Bibliotecas Digitais, disponíveis em https://digitalis.uc.pt/pt-pt/termos.

Conforme exposto nos referidos Termos e Condições de Uso, o descarregamento de títulos de acesso restrito requer uma licença válida de autorização devendo o utilizador aceder ao(s) documento(s) a partir de um endereço de IP da instituição detentora da supramencionada licença.

Ao utilizador é apenas permitido o descarregamento para uso pessoal, pelo que o emprego do(s) título(s) descarregado(s) para outro fim, designadamente comercial, carece de autorização do respetivo autor ou editor da obra.

Na medida em que todas as obras da UC Digitalis se encontram protegidas pelo Código do Direito de Autor e Direitos Conexos e demais legislação aplicável, toda a cópia, parcial ou total, deste documento, nos casos em que é legalmente admitida, deverá conter ou fazer-se acompanhar por este aviso. 
CONIMBRIGA

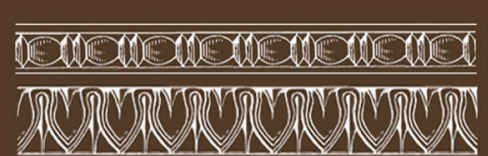

INSTITUTO DE ARQUEOLOGIA

VOLUME XLIII - 2004

FACULDADE DE LETRA

UNIVERSIDADE DE COIMBRA 
RAQUel VILAÇA

Instituto de Arqueologia. Faculdade de Letras da Universidade de Coimbra

ANA MARgarida ARRUdA

UNIARQ. Centro de Arqueologia. Faculdade de Letras da Universidade de Lisboa

AO LONGO DO TEJO, DO BRONZE AO FERRO

"Conimbriga" XLIII (2004) p. 11-45

Resumo: Quer no estuário quer no médio Tejo, a ocupação humana durante o Bronze Final foi intensa. Verifica-se que em ambas as áreas os espólios apresentam similitudes muito significativas, ainda que o tipo de implantação possa, em alguns casos, parecer distinto. A aparente descontinuidade geográfica, em termos de fixação de populações, entre as duas regiões tem sido colmatada por trabalhos recentes nos concelhos de Tomar, Abrantes, Mação e Sardoal, onde têm sido descobertos sítios ocupados no final da Idade do Bronze.

Os dados que emanaram das escavações levadas a efeito na Cachouça, e de outros ainda em estudo no Alto Ribatejo, permitiram constatar que as relações entre as duas regiões permaneceram durante a $1^{\underline{a}}$ metade do I milénio a. C., ainda que se admita que possam ter esmorecido. Com efeito, se é verdade que a densidade da ocupação orientalizante do estuário não tem paralelo no médio Tejo, também parece certo que parte do "pacote" oriental penetrou nele. A orientalização do interior norte peninsular, que atingiu, ainda nas margens do Tejo, Castilla la Mancha, e mais para Sul a Meseta e a Extremadura espanhola pode assim ser explicada por um percurso Oeste/Este, através do Tejo, em detrimento da explicação tradicional que lhe atribuía um sentido Sul/Norte, num trajecto que seguia o que veio a ser a via da prata.

Os dados de um e de outro período são detalhadamente apresentados, no que se refere aos espólios e às tipologias de implantação, não se tendo desprezado os que a paleo-botânica e a paleo-zoologia também já forneceram. E as datações radiométricas obtidas nas duas regiões analisadas foram avaliadas e discutidas. 
Infelizmente, os dados referentes ao mundo funerário não abundam em qualquer das áreas, sendo aqui e agora evidente uma situação de clara invisibilidade tumular. Ainda assim, e mesmo que tenham sido apenas referidos, foram chamados à colação na discussão, sobretudo para evidenciar, também neste caso, a simetria das duas regiões em estudo quanto à simultaneidade de práticas funerárias distintas: a cremação e a inumação.

ABSTRACT: The human occupation during the late Bronze Age in the estuary of the Tagus River, so as in his middle valley, was intensive. We have verified, in both areas, the same materials and the same topographical implantation, even we can observed some distinctive features in the later aspect.

The geographical discontinuity between the two regions is only apparently. Archaeological works in Tomar, Abrantes, Mação e Sardoal have demonstrated the occupation of theses lands also in this period. The data obtained in the excavations of Cachouça, and in others sites of the Alto Ribatejo, allow us to conclude that the relationships between the two areas stay in order in the $1^{\text {rst }}$ half of the I millennium B. C., even we can admitted that they had now lower importance. Effectively, the density of the orientalized Iron Age in the estuary is not comparable to what we could see in the middle valley. But, the true is that some parts of the oriental "package" are also here.

So, we think that we can say that the process of orientalization of same interior areas of the Iberian Peninsula, verified in Castilla la Mancha, Meseta and Estremadura, may be explained by a trajectory West/East, across the Tagus river, and no by the traditional South/North thesis, across the future Silver Route.

All the information's about materials (ceramics, bronze and iron artefacts) and implantation typologies of the two periods are presented and discussed for both areas, and the paleo-botanical and paleo-zoological data are also analysed, so as the radio carbon dates.

The data of the burial aspect are very poor in the estuary so as in the middle valley and a tumular invisibility have been showed. But it becomes clear, also in this case, the symmetry of both regions, in what concern to the funerary practices: cremation and inhumation are verified at the same moments. 


\section{AO LONGO DO TEJO, DO BRONZE AO FERRO}

\section{Introdução}

É sabido que, desde os tempos mais remotos, o grande rio peninsular (com cerca de $1000 \mathrm{Km}$ de extensão) foi alvo de atracção por parte das comunidades humanas. Porém, a história do rio, e das suas comunidades, está ainda por fazer no seu todo. Este texto, centrado nos últimos séculos do II milénio a. C. e nos primeiros do milénio seguinte, é um pequeno contributo para essa história.

Conforme nos recorda Orlando Ribeiro, no território português, o Tejo, sendo um rio de planície, não deixa de apresentar duas faces: a montante, um estreito vale de erosão encaixado nos planaltos do Maciço Hespérico; a jusante, o amplo vale ribatejano, depois fechado a pouca distância do mar (RIBEIRO e LAUTENSACH, 1988: 512).

Naturalmente que estas características foram no passado, tal como hoje, condicionantes da fixação das populações. Por outro lado, o seu próprio regime, de uma irregularidade incontrolável, umas vezes terá aproximado as populações das duas margens, sendo possível atravessar a pé1, outras vezes terá constituído fronteira, isto é, a linha até onde se podia chegar. A sua navegabilidade conheceu igualmente distintas situações. No século XVIII os barcos chegavam a Vila Velha de Ródão (GASPAR, 1970), mas no I milénio a. C. não sabemos se também era assim. Mas, parece certo que, de uma forma ou de outra, pelo menos entre os finais do II milénio a. C. e os meados do I, as duas faces do rio mantiveram relações que os dados arqueológicos puderam provar.

São justamente esses dados que são agora apresentados, tentandose não só explicar o tipo de relações, as suas trajectórias e os seus percursos, como também compreender processos historicamente construídos através do grande rio.

1 Como nos finais de Agosto de 1798, em frente de Santarém (RIBEIRo e LAUTENSACH, 1998, p. 483). 


\section{Do Bronze ao Ferro no curso médio do Tejo}

\subsection{Introdução}

No actual quadro dos conhecimentos, a ocupação do Bronze Final do curso médio do Tejo apresenta um número significativo de registos a norte do rio, quer nas zonas mais ribeirinhas, quer nas áreas mais interiores. Pelo contrário, na margem sul, a ocupação humana de há cerca de 3000 anos é praticamente desconhecida. Tal situação poderá dever-se a um povoamento realmente escasso, pouco expressivo ou de baixa visibilidade que, a confirmar-se, implicaria a formulação de interessantes questões; mas também poderá traduzir, simplesmente, uma situação de déficit de investigação. Esta problemática deverá ser, por outro lado, equacionada com a expressão espacial e cultual do "Santuário do Vale do Tejo", cujo território, sagrado por natureza, parece ter funcionado como um interdito a ocupações mais "profanas" (VILAÇA, 2000a: 176). Quer isto dizer ainda que, na margem norte, os sítios que vulgarmente designamos por povoados encontram-se afastados do rio. Além destes povoados, conhecem-se outras possíveis categorias de registos reportáveis ao Bronze Final - "estelas", "depósitos" de bronze, achados avulsos, locais de exploração de matéria-prima - sendo que esta classificação e, consequentemente, a sua valorização, poderão funcionar de forma inoperante e deformadora numa aproximação às comunidades da época (VILAÇA, 2000b: 32).

Partindo das zonas mais próximas do rio para o interior, e de montante para jusante, regista-se um interessante número de testemunhos no sul dos concelhos de Idanha-a-Nova e Castelo Branco, e ainda nos concelhos de Vila Velha de Ródão, Mação, Sardoal e Abrantes. Mais para o interior é de destacar o estudo desenvolvido na designada "Plataforma de Castelo Branco" e abas orientais das serras da Cordilheira Central (Estrela, Malcata e Gardunha) (VILAÇA, 1995).

Naturalmente que a qualidade de todos esses testemunhos é muito díspar: uma minoria de sítios foi alvo de escavações, sempre parciais, regidas por metodologia adequada, enquanto que, de outros, a maioria, sabemos apenas da sua existência, em regra com base em materiais cerâmicos de superfície. Ao nível dos materiais, as escavações proporcionaram múltiplos e diversificados registos, entre os quais os artefactos metálicos assumem inequívoca importância. Até então, os bronzes desta região não dispunham de contexto arqueológico conhecido, o que nos 
proporcionava uma imagem muito parcial e distorcida da produção e circulação e deposição desse metal. Por outro lado, essas mesmas escavações permitiram a recolha de elementos orgânicos, carvões e fauna, essencialmente. Para além de informações de outra natureza, foi possível obter datas de C14 (VILAÇA, 1995: 372-379); por exemplo, pela primeira vez, foi possível datar com critérios não tipológicos as designadas cerâmicas de "tipo Lapa do Fumo", que podem recuar aos dois últimos séculos do II milénio a. C.

Pelo contrário, a Idade do Ferro no médio Tejo é praticamente desconhecida. Os dados não abundam, a sua qualidade é discutível, a sua cronologia mais específica também. Constitui excepção o sítio da Cachouça (Idanha-a-Nova), sobranceiro ao Ponsul, onde sondagens recentes permitiram a identificação de testemunhos inseríveis nos inícios da fase sidérica (VILAÇA e BASÍLIO, 2000; VILAÇA, no prelo b). Outros elementos apontam para ocupações posteriores, algumas muito tardias, designadamente em ou próximo de povoados já ocupados nos finais da Idade do Bronze, como sucede em Monforte da Beira (Castelo Branco) e, mais para norte, na Argemela e Tapada das Argolas (Fundão). Noutros casos, como Idanha-a-Velha, Monsanto, Cabeço dos Mouros (Idanha-a-Nova), Castelejo, no Tostão (Vila Velha de Ródão), a informação é mais imprecisa ou reportável a um período de finais do milénio. Trabalhos antigos, recentes ou em curso, nas zonas de Mação e Abrantes também proporcionaram nova informação, quer dos finais da Idade do Bronze, quer da Idade do Ferro ${ }^{2}$.

\subsection{Os sítios e os materiais}

\subsubsection{O Bronze Final}

Estratigrafias, materiais e datas de $\mathrm{C} 14$ permitem-nos dizer que a ocupação dos sítios de habitat de finais da Idade do Bronze no médio Tejo remonta aos sécs. XI-X a. C.; alguns poderão ter conhecido uma ocupação de 200 a 300 anos, após a qual foram, definitiva ou temporariamente, abandonados. Constitui excepção o caso da Cachouça, ocupado no Bronze Final-Ferro Inicial, que comentaremos adiante.

2 Em particular, escavações da responsabilidade de Paulo Félix nos sítios da Quinta da Pedreira (Abrantes) e do Castelo do Cabeço das Mós (Sardoal) realizadas no âmbito da tese de doutoramento que prepara. 
Todos eles correspondem a sítios de altura, em regra relevos bem destacados na paisagem e, não raras vezes, encimados por núcleos gigantescos de afloramentos, o que lhes confere uma peculiar fisionomia. Estes atributos deverão ter sido fundamentais na construção de processos de identificação e na construção de territorialidades, no âmbito do que pode designar-se por uma "geografia cognitiva". De facto, mesmo que a cobertura vegetal da região fosse substancialmente diferente daquela que hoje percepcionamos, a visibilidade dos sítios e para os sítios não estaria em causa.

As plataformas de topo são sistematicamente ocupadas e, por vezes, muralhadas. É certo que, na região, são diversos os sítios que possuem muralhas, mas a sua cronologia não é reportável, de forma inequívoca, ao Bronze Final. O problema é, aliás, comum ao território português, conforme já foi sublinhado por uma de nós e posteriormente reiterado (VILAÇA, 1995: 257; JORGE, 1997: 17; BETTENCOURT e SANCHES, 1998: 31). Uma das excepções é, por exemplo, a muralha do Monte do Trigo (Idanha-a-Nova), onde foi identificada uma sugestiva deposição ritual bimetálica, de bronzes e ferros datável do Bronze Final ${ }^{3}$. Se uma das funções atribuídas às muralhas é a de, simplesmente, demarcar o espaço habitado, então é compreensível a inexistência de muralhas em alguns daqueles sítios cujas plataformas são, natural e fisicamente, delimitadas: o espaço habitado termina quando à horizontalidade "domesticável" da plataforma sucede a verticalidade da escarpa, essa, sim, "selvagem".

De um modo geral, os povoados são de dimensão modesta ou mesmo muito modesta, como o Monte do Frade (Penamacor), reduzido a pouco mais de $130 \mathrm{~m}^{2}$. Aqui, no topo de tudo, foi escavada uma área de cabana com cerca de $30 \mathrm{~m}^{2}$, possuindo lareira central e dois buracos de poste, cuja localização, próxima de um empedrado ladeado por afloramentos, torna plausível a existência de uma espécie de átrio de acesso àquela. Na sua periferia foram identificados diversos afloramentos com "covinhas", constituindo, certamente, elementos de demarcação simbólica do espaço (VILAÇA, 1997b). Os maiores povoados, como Monforte ou a Tapada das Argolas, conheceram ocupações tardias, do final da Idade do Ferro, num momento em que os contactos da região com o mundo romano republicano já eram, contudo, uma realidade.

O povoamento insere-se, assim, num modelo pautado por uma organização de forte pendor multipolar. A população, embora dissemi-

3 Escavações da responsabilidade de uma das autoras (R. V.), ainda inéditas. 
nada no espaço, não estava isolada, uma vez que a intervisibilidade entre vizinhos é assinalável. A comunhão de territórios imposta pela própria natureza deverá ter constituído elemento fomentador mais de solidariedades do que de competitividades e individualismos. Estas, inerentes a qualquer sociedade e próprias do ser humano, conheceram, à época, formas peculiares de manifestação e de legitimação expressas em rituais celebrados em actos públicos. Como veremos, alguns dos materiais conhecidos poderão articular-se com esta problemática.

Em termos micro-espaciais, estes sítios conhecem uma incipiente organização, com frustes cabanas entre penedos, elas próprias construídas com materiais perecíveis ainda que alicerçados por sapatas de pedra, por vezes duplas, como na Moreirinha (Idanha-a-Nova). Também o espaço habitado parece ter sido ambi(poli)valente, congregando, alternada ou cumulativamente, funções diferentes mas não incompatíveis (VILAÇA, 2000b: 35). O quotidiano parece ter sido gerido nos mesmos espaços em que o contrário, isto é, o excepcional - festivo, comemorativo, funerário - ocorria. Poderes e tensões sociais teriam expressão nos sítios onde se vivia, o que lhes confere capitabilidade social e territorial. Neste sentido, uma mais correcta (ou alternativa) leitura das "estelas", "depósitos" e achados avulsos, deve ser feita a partir, e em função, dos sítios habitados.

Contrariamente à zona do estuário, nesta região não são conhecidos sítios implantados em cotas baixas, sem quaisquer preocupações em termos defensivos, de visibilidade ou de domínio, consagrados na literatura científica por "casais agrícolas". Poderão, simplesmente, não existir; mas também a falta de prospecções em plataformas de baixa altitude poderá explicar tal situação. O que de mais próximo existe é o caso, de resto, intrigante, das designadas "estruturas 1 e 2" do Monte de São Domingos (Castelo Branco), de carácter habitacional, segundo os investigadores que as analisaram (CARDOSO et alii, 1998). No interior de uma dessas estruturas, subcircular, foi recolhida uma urna com ossos humanos (que muito interessaria datar), isto é, corresponde a uma sepultura de incineração. Se é verdade que a morte no Bronze Final invadiu os mais diversos e inesperados espaços, inclusive, os de habitat, não podemos deixar de perguntar que outras "actividades" decorreram nessas cabanas do Monte de São Domingos? Sem dúvida, uma estação a ser revisitada (VILAÇA, 2000a: 176 e nota 21).

Já entre o baixo e o médio Tejo, numa região de transição, foram identificadas as duas modalidades de povoamento, uma associada às 
terras férteis do vale do rio, caso da Quinta da Pedreira (Abrantes), alvo de escavações (FÉLIX, 1997: 36; 2000: 730), e outros, destruídos pelo IP6 (SILVA et alii, 1999: 260); ao mesmo grupo poderemos ainda associar sítios como a Quinta do Vale do Zebro e Amoreira/Quinta da Légua, ambos muito próximos daquele (SILVA et alii, 1999: 257-258) e Tramagal (Abrantes) (BATATA et alii, 1999: 28). A outra reúne povoados de cumeada, casos do Castelo Velho do Caratão (Mação), Fortaleza de Abrantes (PereIRA, 1971; 1988; BüBNER, 1996), ou Castelo da Cabeça das Mós (Sardoal) (SiLva et alii, 1999: 260).

Coloca-se aqui, tal como no baixo Tejo (cfr. 3.2.1.), a questão da total/parcial ou nenhuma contemporaneidade destes dois modelos de povoamento. Na zona do estuário, existem já elementos ergológicos e cronométricos que sustentam uma discussão consistente, como se verá. Para a região de Abrantes/Sardoal, o problema será certamente discutido por Paulo Félix com base em elementos inéditos resultantes da sua própria investigação.

O que poderemos adiantar é que, na bacia do Tejo, não parece ser viável a aplicação do binómio metalurgia do bronze/povoados de altura, excluindo-se os "casais agrícolas" da esfera da produção e circulação do bronze. Quer a foice de "tipo Rocanes" da Quinta do Vale do Zebro (Abrantes), quer o molde do mesmo tipo do casal de Rocanes (Sintra), quer ainda o molde de fundição de Cotão 3 (Sintra) e os artefactos de bronze de Gamelas 3 e Abrunheiro (Oeiras) (MARQues, 1994: 66-67)4, pertencem a sítios articuláveis com "casais agrícolas", o que prova a intromissão do bronze nos distintos tipos de habitat. Interessante é ainda, neste mesmo tipo de sítios, a coexistência de elementos de foice líticos e de foices metálicas, o que nos levaria à discussão da real funcionalidade destas últimas (VILAÇA, 1995: 332), aspecto que não podemos, todavia, aqui desenvolver.

Tal como o bronze ocorre nos "casais agrícolas", também a agricultura era praticada, juntamente com a pastorícia, pelas populações residentes nas cumeadas. O peso da vocação agrícola e metalúrgica de uns e de outros não está em causa, mas deverá ser relativisada.

A presença sistemática e, por vezes, em abundante número, de elementos de moinho (dormentes e moventes) nos sítios de altura constitui

4 Infelizmente, materiais, entre muitos outros, que o proprietário nunca publicou em vida e que continuam inacessíveis, conforme uma das autoras deste texto (R. V.) teve já possibilidade de confirmar junto de quem de direito. 
uma prova indirecta da actividade de moagem. $\mathrm{O}$ uso intensivo destes instrumentos está plasmado no desgaste, por vezes até à exaustão, das suas superfícies, bem como nas peças bidormentes. A sua inclusão como material de construção em cabanas, lareiras e muretes, alguns ainda em condições de funcionarem, autoriza a pensar num eventual papel ritual ligado ao culto da terra, tanto mais porque nos contextos em causa o que não faltava era matéria-prima em bruto para construção. É certo que bens não cultivados, como a bolota, necessitavam de ser triturados, e foram-no, por certo. Mas o cultivo do trigo e da cevada era também conhecido como provam as impressões de grãos desses cereais em cerâmicas dos Alegrios, Moreirinha, Monte do Frade, Monte do Trigo e Cachouça (VILAÇA et alii, 2004).

A criação de gado bovino, caprino e suíno fazia parte das actividades da Moreirinha, Monte do Frade e Alegrios (Idanha-a-Nova) (ANTUNES, 1992; VILAÇA, 1995: 368), bem como do Monte do Trigo (Idanha-a-Nova). Trata-se de conjuntos relacionados com estruturas de combustão ou fossas detríticas, constituindo restos alimentares, o que explica, em parte, o acentuado grau de fragmentação que apresentam. Predominam as peças do esqueleto apendicular e foram alvo de descarnação e possível consumo da medula. Verificou-se a existência de marcas de mordidelas denunciadoras da presença de cão. Foi reconhecida a falta de indícios seguros de caça. $\mathrm{O}$ estudo de outros conjuntos faunísticos coevos, que permanecem inéditos, como o do Castelo Velho de Caratão (Mação), poderá vir a confirmar este quadro ou, pelo contrário, mostrar que a caça era igualmente praticada. A cena do designado "Menir de São Martinho" (Castelo Branco) é conectável com actividades cinegéticas protagonizadas por personagens de relevo na sociedade (VILAÇA, 1995: 403), mas uma cabal avaliação contextual desta actividade nos finais da Idade do Bronze merece mais atenção futuramente.

O repertório cerâmico atribuível à transição do II para o I milénio a. C. é riquíssimo em termos tipológicos e estilísticos, reflectindo bem a diversidade de influências que esta região do médio Tejo assimilou. Destacam-se as cerâmicas com decoração brunida (nas duas variantes de sulcos e faixas) de "tipo Lapa do Fumo", com formas e motivos altamente padronizados. Estão igualmente presentes, ainda que de forma residual, exemplares com decoração brunida em ambas as superfícies (Alegrios). A título excepcional, também ocorrem as cerâmicas pintadas de "tipo Carambolo" (Moreirinha, Tapada das Argolas e Cachouça), as cerâmicas de "tipo Baiões" (Alegrios e Cachouça) e as cerâmicas de 
âmbito Cogotas (Monte do Frade e Moreirinha). Importa ainda sublinhar que, a par destes exemplares, existem outros não decorados, mas de fabrico igualmente fino e cuidado, com superfícies integralmente polidas e brunidas. Além destas cerâmicas de excepção, contam-se também as de fabrico mais grosseiro ou menos cuidado, nomeadamente as designadas "cepilladas", particularmente expressivas nos grandes potes de armazenagem.

A pedra foi utilizada nos elementos de moinho, em moldes e ainda em pesos de tear e/ou pesca (Alegrios, Moreirinha, Monte do Frade, Monte de São Martinho e Cachouça); neste caso trata-se de pequenos seixos naturais com entalhes laterais obtidos por percussão, cujos pesos oscilam entre 20 gr e 114 gr. Temos também contas de colar em azeviche, ágata e cornalina, bem como de vidro (Alegrios, Monte do Trigo e Cachouça) e âmbar de origem báltica (Moreirinha) (CURT e VILAÇA, 1995). Neste último caso a sua importância é manifesta na análise da circulação e das trocas inter e trans-regionais desenvolvidas na época.

Os mesmos contextos dos ecofactos, dos materiais cerâmicos e líticos referidos, forneceram provas sistemáticas e significativas da produção do bronze. Com efeito, podemos falar numa "domesticidade" da metalurgia do bronze, bem expressa nos cadinhos, fragmentos de algaravizes, moldes (líticos e cerâmicos), pingos e restos de fundição, instrumentos inacabados e outros presentes em múltiplos povoados: Argemela, Monforte da Beira, Monte de São Martinho, Alegrios, Moreirinha, Monte do Trigo, Monte do Frade, Castelo Velho do Caratão, etc. Um número muito significativo de análises autoriza-nos a dizer que a metalurgia do Bronze Final do curso médio do Tejo é uma metalurgia binária e, em geral, de muito boa qualidade (VILAÇA, 1997). Pelo contrário, as raras análises a que foram submetidas algumas peças já de cronologia sidérica acusam ligas ternárias (VILAÇA et alii, 2002-2003).

Os materiais metálicos do curso médio do Tejo são numerosos e diversificados em termos tipológicos e funcionais que, como é sabido, nesta altura, integra igualmente elementos de cariz mediterrâneo. Para além dos contextos habitacionais, encontram-se nos designados "depósitos” - Paul (Covilhã), Ervedal (Fundão) e Porto do Concelho (Mação) - e também se conhecem diversos achados isolados. Estes estão fundamentalmente representados por machados (planos, monofaces, de talão com uma e duas argolas, de alvado com uma e duas argolas, de apêndices) que, pelo contrário, não têm expressão directa em contextos habitacionais. Contam-se, entre outros, inúmeras argolas (abertas e fecha- 
das, grandes e pequenas, circulares e elípticas, com e sem apêndice), escopros (com destaque, pela sua raridade, para o punção oco da Moreirinha), hastes e varetas (VILAÇA, 1995: 338). E ainda foices de "tipo Rocanes" de Porto do Concelho (Mação) e da Quinta do Vale do Zebro (Abrantes), punhais do Monte do Frade, Moreirinha, Monforte da Beira, Castelo Velho do Caratão, Porto do Concelho e Ervedal, espadas, nomeadamente de "tipo língua de carpa" (Tapada das Argolas, Alegrios, Monte de São Martinho, Castelo Velho do Caratão, Ervedal, Porto do Concelho), "tranchets" (Monte do Frade, Castelo Velho do Caratão, Tapada das Argolas, Monte do Trigo e Cachouça), botões, com e sem apêndice (Alegrios, Moreirinha, Monte do Trigo, Tapada das Argolas), braceletes (Monte do Frade, Moreirinha, Monforte da Beira, Castelo Velho do Caratão, Porto do Concelho e Ervedal), pinças (Monte do Frade e Monte do Trigo), fíbulas e molas de fíbula (Alegrios, Monte do Frade, Monte de São Martinho, Cachouça), caldeirões (Monte de São Martinho e Cachouça), espetos (Cachouça e talvez Moreirinha), ponderais (Moreirinha e Monte do Trigo), etc. Estes últimos, aliás como também os provenientes dos povoados de Penha Verde (Sintra), da Ota (Alenquer), Pragança (Cadaval) e Abrigo Grande das Bocas (Rio Maior), já do baixo Tejo, são particularmente interessantes pelo seu significado (VILAÇA, 2003).

Ao nível da manipulação dos metais, importa ainda sublinhar a precoce incorporação de artefactos de ferro num quadro regional de pujante metalurgia do bronze. De facto, se há uma década atrás esta situação constituía uma excepção, hoje o número de casos aumentou, quer nesta região, quer noutras áreas do ocidente peninsular Os materiais de ferro expressam-se, de forma esmagadora, através de pequenas lâminas de faca e de serra (Moreirinha, Monte do Frade, Monte do Trigo), peças essas que podem incorporar rebites de bronze (Cachouça). Considerámos inicialmente que a sua presença se articularia liminarmente com a problemática da importação de bens de prestígio, mas o seu significado parece-nos hoje menos evidente e, consequentemente, mais complexo, colocando inúmeras questões (VILAÇA, no prelo a). Seja como for, sendo um problema tecnológico (trata-se da redução do ferro, não da sua fundição), que sabemos ter sido prolongado no tempo, com adesões fáceis (até que ponto conscientes?), mas também com resistências, terá de ser abordado regionalmente, na longa diacronia e articulado com as dinâmicas sócio-económicas. No fundo, importa captar a natureza social e o valor dos dois ferros, o do Bronze e o do Ferro. É por isso que 
não nos revemos em afirmações simplistas, como a de que "Uma vez descoberta a metalurgia do ferro, verificou-se que o novo metal era na verdade revolucionário, pois permitia o refundir [?!] de objectos danificados sem que as qualidades do metal se alterassem" (GAMITO, 2002: 126).

Apesar da importância aurífera da bacia do Tejo, as jóias conhecidas na região resumem-se aos dois braceletes de ouro maciço de Monforte da Beira e da Soalheira (Fundão) e à bráctea do Sobreiral (Fundão). Tal situação contrasta com a da vizinha Extremadura, onde o número de achados parece ser bem superior, não obstante tratar-se de uma área muitíssimo maior.

A época que analisamos coincide com o colapso do milenar "Santuário do Vale do Tejo". Após sucessivas transformações e transfigurações, este verdadeiro lugar monumentalizado, conheceu, na sua última fase - "período de círculos e linhas" -, a inscrição de diversos elementos, como serpentiformes, círculos, ferraduras, podomorfos, bem como as gravuras de duas espadas na rocha 53 do Cachão do Algarve e o escudo com escutadura em "V" da rocha 29 do mesmo núcleo (GoMEs, 1987). O santuário está ainda operacional, mas em manifesta decadência, e é este contraste que importa sublinhar: no final da Idade do Bronze, o santuário "esvazia-se" e os espaços habitacionais adquirem uma visibilidade que traduz uma absorção de poderes, inclusive cultuais (VILAÇA, 2000a: 176-177; 2000b: 35-41).

\subsubsection{A Idade do Ferro}

Como referimos, a Idade do Ferro do médio Tejo é muito mal conhecida e, consequentemente, de traçado inseguro. Os únicos elementos que podemos inscrever no que se designa por I Idade do Ferro circunscrevem-se a um único caso - a Cachouça (Idanha-a-Nova) - com todas as limitações que tal implica, e até pelo facto de ter sido apenas parcialmente escavada 5 .

Sem ser possível generalizar, pelo motivo que acabámos de expor, certo é que a Cachouça revela uma alteração na lógica do povoamento que marcou a região no Bronze Final. Contrariamente a tudo o que é conhecido, o sítio da Cachouça corresponde a uma área planáltica que define o remate de um esporão. Tal como no passado, a visibilidade para

\footnotetext{
5 Em fase de estudo por uma das autoras (R. V.).
} 
fora mantém-se, mas é agora orientada para sul e nascente, por onde correm o Ponsul, a barroca da Canada e o rio Torto, afluentes daquele. A individualidade física, de amplos e totais horizontes, tão característica dos sítios do Bronze Final, dilui-se, e a Cachouça surge dissimulada na paisagem; apenas de determinados pontos do vale, hoje transformado pela "Barragem Marechal Carmona", se identifica o esporão.

Na sequência de uma ocupação do Bronze Final, o sítio continuou a ser habitado, ao que tudo indica (materiais e datações de C14), durante os sécs. VIII-VI a. C. A profunda destruição que sofreu, na sequência de trabalhos agrícolas e de pastagens para gado, afectou a conservação de estruturas e estratigrafias, criando problemas de difícil solução. Por exemplo, podemos encontrar nas mesmas camadas, materiais atribuíveis ao Bronze Final, com outros do Neolítico-Calcolítico (1. o ocupação do sítio) e cerâmicas feitas a torno.

Uma das particularidades registada é a existência de um singular talude. Trata-se de uma barreira artificial, em pedra e terra, de planta grosseiramente elíptica, orientada de NW/SE, que delimita uma área de cerca de $900 \mathrm{~m}^{2}$; a sua largura original poderá ser estimada em cerca de 2,5 m; actualmente conserva uma altura de aproximadamente $1 \mathrm{~m}$. Presumivelmente, haverá uma entrada localizada a SE, junto a um dos acessos que conduz aos vales dos rios Torto e Ponsul.

Para além da implantação topográfica, que corta com a estratégia do passado, o que importa sublinhar é a nova concepção e inteligibilidade do espaço, que é agora polarizado por uma barreira física artificial - o talude - que fecha uma espaço, ou antes, define dois espaços, um interior e fechado, outro exterior e aberto.

$\mathrm{Na}$ zona norte foi escavada uma cabana de planta circular, no centro da qual existia uma lareira. É sugestiva a sua implantação no alinhamento do talude e a anexação de diversas outras estruturas, como fossas, muretes, pisos em argila (alguns decorados com incisões).

Tal como no período anterior, esta fase é marcada pela incorporação de diversificadas influências assimiladas das suas múltiplas "periferias": às cerâmicas de ornatos brunidos de "tipo Lapa do Fumo", de "tipo Baiões", com finas incisões pós-cozedura e pintadas de "tipo Carambolo", juntam-se as típicas cerâmicas penteadas ou "peinadas" do mundo mesetenho. Acrescem ainda as significativas cerâmicas a torno, designadamente as cinzentas finas, de inspiração fenícia, mas de fabrico certamente ocidental (VILAÇA e BASÍLIO, 2000). Revelam uma inequívoca descontinuidade relativamente às cerâmicas de tradição do Bronze 
Final, quer ao nível da técnica de fabrico, quer em termos de cozedura, quer em termos de uma nova estética formal.

Outro tipo de artefactos, como as contas oculadas, o fragmento de pasta vítrea tricolor pertencente a uma pequena anforeta, os elementos zoomórficos de terracota (possível ave), ou a importância de certos artefactos de ferro, como um longo punhal de lâmina triangular, reforçam tal descontinuidade, que é, porém, insuficiente para alterar a marca cultural da região. Continuamos num tempo de coexistências, com a manutenção de tradições (a metalurgia do bronze, por exemplo) e a assimilação de novidades (de cariz mesetenho e mediterrâneo).

A 1. ${ }^{\text {a }}$ Idade do Ferro no médio Tejo reduz-se, de momento, a um enclave, a Cachouça. Nessa altura, a Extremadura espanhola optara por uma via orientalizante e, o baixo Tejo, caminhava de alguma forma na mesma direcção ainda que percorrendo caminhos distintos. Cabe perguntar, ainda que não seja possível responder de momento, se o médio Tejo rompeu com essa tendência de globalização orientalizante que atingiu o SW, ou se a sua posição física e cultural foram condicionantes no traçado de uma outra via. Pelo exemplo da Cachouça, a segunda hipótese assume-se como a mais credível. De facto, não obstante a existência de novos marcadores de índole mediterrânea, este mundo indígena mais interior e afastado das "periferias" de Tarteso é marcado por ancestrais ligações ao mundo mais setentrional, atlântico e mesetenho, que permanecem. É de sublinhar que a assimilação desses novos elementos foi feita de forma selectiva. Nem as cerâmicas a torno, nem os artefactos de vidro e de ferro, nem os elementos zoomórficos coroplásticos arrastaram consigo novas concepções arquitectónicas, que mantêm a matriz circular, ou a própria escrita.

A forma como, nos séculos seguintes, prosseguiu e se transformou este diálogo transcultural é praticamente desconhecida. Os parcos elementos disponíveis, dispersos e mal contextualizados, necessitam de ser trabalhados e articulados com os lugares que, como Monforte da Beira, Monte de São Martinho ou a Tapada das Argolas são de novo reocupados. Materiais recentemente estudados provenientes deste último, como as placas de bronze decoradas, a fíbula "de cavalinho" ou a espada de ferro de tipo "La Tène", justificam que se prossiga a investigação (VILAÇA et alii, 2002-2003). 


\section{No estuário do Tejo, do Bronze ao Ferro}

\subsection{Introdução}

Durante o Bronze Final, a ocupação das margens do antigo estuário do Tejo, bem como aliás das áreas imediatamente anexas, para Norte, parece ter sido intensa. Com efeito, a lista de sítios arqueológicos onde uma ocupação desta época foi detectada é vasta. Nos concelhos de Sintra, Loures, Cascais, Mafra, Oeiras, Amadora, Lisboa e Almada, os povoados onde se registaram elementos datáveis do referido período são numerosos. Se a essa lista acrescentarmos, também, os chamados "depósitos votivos" ou "esconderijos de fundidor", encontrados na Estremadura portuguesa, a ocupação humana desta área e deste período assume uma dimensão considerável, parecendo que a região adquiriu então grande vitalidade. A imagem dessa vitalidade seria, porventura, ainda mais nítida, se alargássemos a toda a Estremadura e mesmo ao Alto Ribatejo a análise, uma vez que em Torres Vedras, Alenquer, Bombarral, Cadaval, Óbidos, Rio Maior, Alcanena e Torres Novas, os achados de materiais associados ao final da Idade do Bronze, quer em grutas quer em sítios de ar livre, são abundantes.

Infelizmente, a qualidade de informação disponível não é proporcional à sua quantidade. $\mathrm{O}$ que se conhece da grande maioria destes sítios é quase nada, existindo apenas breves notícias que registam, maioritariamente, achados de superfície. Outros casos remetem-nos para intervenções arqueológicas realizadas em época em que as metodologias não obrigavam a um registo suficientemente rigoroso que permita, hoje, o real entendimento do significado dos materiais que aparecem agora descontextualizados.

Não queremos ainda deixar de referir que, no conjunto dos dados que possuímos sobre o Bronze Final estremenho, se destacam os objectos metálicos. Com efeito, se é verdade que a densidade deste tipo de achados é vasta na região, a sua sobrevalorização face a outros elementos, concretamente as cerâmicas, deve-se a razões que se prendem com a própria história da Arqueologia em geral e ainda porque o estudo tipológico dos objectos de bronze foi durante largos anos confundido com o próprio percurso da investigação sobre a Idade do Bronze.

A Tapada da Ajuda (Lisboa), o Moinho da Atalaia (Amadora) e Almaraz (Almada) são, portanto, os únicos sítios localizados na foz do estuário do Tejo, cujos dados podem ser manejados com alguma 
segurança, uma vez que resultam de escavações arqueológicas relativamente recentes.

Mais para Norte, mas ainda no antigo estuário, situam-se os sítios que estiveram na base da criação de um dos mais controversos "conceitos" da Proto-história portuguesa: a "cultura de Alpiarça". E se as circunstâncias das antigas recolhas contribuíram para criar algum malestar em relação àqueles achados, a verdade é que as novas intervenções dos anos 80 do século XX não o esbateram completamente, ainda que a cronologia dos enterramentos tenha ficado melhor esclarecida. Quanto a esta última questão, um trabalho recente que uma de nós realizou em colaboração com outros autores (VILAÇA et alii, 1999) permitiu, contudo, uma mais precisa aferição.

Ao contrário do que se passa em relação ao final da Idade do Bronze, para o início da ocupação sidérica das margens do antigo estuário e regiões limítrofes contamos com dados que, não sendo tão abundantes, são, na sua grande maioria, mais fiáveis.

As escavações levadas a efeito em Almaraz, Lisboa, Santarém, Outorela, Moinhos da Atalaia, Freiria são recentes e proporcionaram elementos que permitem definir cronologias e culturas materiais que ajudam a traçar um perfil relativamente seguro da ocupação humana da região na primeira metade do $10^{\circ}$ milénio a. $\mathrm{C}$.

Mais para Norte, já no Ribatejo, projectos de investigação em curso têm também trazido informação relevante para o estudo do final da Idade do Bronze entre o estuário e a Beira Interior.

São estes portanto os dados que serão aqui apresentados, tendo esta breve introdução servido para ilustrar a diversidade de informação com que pudemos lidar.

\subsection{Os sítios e os materiais}

\subsubsection{O Bronze Final}

Devemos começar por dizer que os povoados da região do Baixo Tejo ocupados durante o final da Idade do Bronze correspondem, na sua grande maioria, a sítios bem destacados na paisagem, com áreas relativamente amplas, aparentemente rodeados por linhas de muralhas, ainda que a cronologia destas seja discutível. Neste esquema, incluem-se, por exemplo, o Castelo dos Mouros, em Sintra (CARDOSO, 1997/1998), 
o Penedo do Lexim (Kalb, 1980; Sousa et alii, 2004), a Serra do Socorro e o Cabeço dos Moinhos (Vicente e ANDRADE, 1971), em Mafra, a Quinta do Almaraz, em Almada (BARRos et alii, 1993; BARRos, 2000), o Castro da Ota, em Alenquer (BArbosa, 1956), o Cabeço Mouro, em Oeiras (CARdoso e CARdoso, 1996) e o Monte da Pena, em Torres Vedras (MADEIRA et alii, 1972).

Para além desta realidade, há que registar a existência de um outro tipo de povoamento, que comporta sítios implantados em cotas baixas, de extensão reduzida e nos quais não se vislumbra qualquer preocupação em termos defensivos. São os chamados "casais agrícolas", de que a Tapada da Ajuda, Lisboa (CARDOSO, 1994; 1995) se constitui um bom exemplo. Neste grupo, pode ainda incluir-se a Quinta do Percevejo e a Quinta do Marcelo, em Almada (BARROS e EsPírITO SANTO, 1991) e os Moinhos da Atalaia na Amadora (PINTO e PARreirA, 1978). Dos numerosos sítios que Marques e Andrade (1974) incluem na longa lista que enforma este tipo, pouco ou nada sabemos, a não ser que se concentram nos concelhos de Oeiras, Sintra e Cascais.

Uma das questões que se levanta a propósito destas duas categorias de sítios é, justamente, a sua sincronia. Com efeito, a cronologia de ambas as estratégias de povoamento, lida nas datações radiométricas existentes, mas também na tipologia dos materiais arqueológicos recolhidos, configura dois tipos de situações distintas.

Assim, parece claro que o início do Bronze Final, na área do estuário do Tejo, foi marcado por uma realidade arqueológica plasmada, por exemplo, na Tapada da Ajuda. Essa realidade, que é caracterizada pela ocupação de encostas suaves, sem condições naturais de defesa, e por estruturas habitacionais de planta oval, com cerca de $6 \mathrm{~m}$ de eixo maior (CARDOSO, 1994; 1995), tinha uma forte componente agrícola, da qual falam os muitos elementos de foice, denticulados de sílex, encontrados no sítio de Lisboa. Ao nível de espólio cerâmico, destaca-se a ausência de decoração de retícula brunida, ainda que o brunimento tenha sido uma técnica utilizada no acabamento das superfícies dos vasos. As técnicas decorativas resumem-se a incisões e impressões sobre o bordo (Ibid.).

Esta etapa antiga do Bronze Final foi datada pelo radiocarbono na Tapada da Ajuda, tendo as datações obtidas permitido que ela se possa situar nos últimos dois séculos do $2 .^{\circ}$ milénio a. C.

Se é verdade que o abandono da Tapada da Ajuda na viragem do $2 .^{\circ}$ para o $1 .^{\circ}$ milénio a. C. poderia permitir que se admitisse que este 
modelo de povoamento se esgotou e foi substituído por outro, o certo é que outros sítios, como Moinhos da Atalaia, na Amadora, (PINTO e PARREIRA, 1978), e Quinta do Percevejo, em Almada (BARRos e EsPírITO SANTO, 1991) parecem ser coevos dos extensos e fortificados povoados de altura, a avaliar não só pelo registo arqueológico, mas também pelas datações radiométricas obtidas para o sítio almadense (BARROS, 2000). Com efeito, nos dois últimos "casais agrícolas" citados as cerâmicas com decoração de tipo "Lapa do Fumo" estão presentes e as análises de radiocarbono obtidas para a Quinta do Percevejo forneceram uma cronologia localizada entre os séculos XI e X a. C. (Ibidem).

Ainda que os dados sejam demasiado escassos, parece possível aceitar que a fundação dos povoados de altura da Estremadura tenha sido, efectivamente, mais tardia que a maioria dos casais agrícolas. Por outro lado, os elementos que podem deduzir-se da escavação da Tapada da Ajuda indiciam uma tendência para o abandono dos pequenos povoados, ainda que os dados de Moinhos da Atalaia e da Quinta do Percevejo possam também configurar a coexistência, nos finais do $2 .^{\circ}$ milénio a. C., dos dois tipos de povoamento.

De qualquer modo, parece certo que num momento localizado na transição do $2 .^{\circ}$ para o $1 .^{\circ}$ milénio a. C. se assistiu, na foz do estuário do Tejo, e nas áreas anexas, a uma concentração de população em locais estratégicos e de grande defensibilidade natural, que substitui um modelo de povoamento disperso e, aparentemente, pouco ou nada hierarquizado. Esta substituição do modelo de povoamento parece ser consentânea com o que é conhecido para outras regiões peninsulares, nomeadamente o Alentejo (Mataloto, 1999: 346-347; CALAdo et alii, 1999: 377).

A sobrevivência ou mesmo a fundação de pequenos povoados ou "casais agrícolas" nesta mesma época pode, contudo e como já atrás referimos, ser defendida, podendo deduzir-se destes dados que terá sido neste momento que se inicia um processo onde se esboçam relações de subordinação entre sítios, em que alguns dependeriam de outros.

Como também acontece nas outras regiões peninsulares, as evidências de necrópoles deste período são inexistentes na área do estuário do Tejo, e, em relação à Estremadura em geral, discute-se ainda a real função das cavidades naturais onde se recolheram espólios com esta cronologia. Com efeito, se a hipótese de se tratar de locais de enterramento parecia, até há pouco tempo, indiscutível, outras possibilidades têm vindo a ser defendidas. A evidência da prática metalúrgica no interior da Gruta da Avecasta permitiu a alguns (KunST, 1995) defenderem 
que neste caso se está perante um local de povoamento; uma função religiosa foi igualmente avançada para as ocupações do Bronze Final das grutas do maciço calcário estremenho (SILVA e GOMES, 1992: 121; CARDOSO et alii, 1999; CARDOSO, 1999/2000).

Já fora da região sobre a qual incide este nosso trabalho, o monumento de falsa cúpula da Roça do Casal do Meio, em Sesimbra (SPINDLER et alii, 1973-74), é indiscutivelmente lugar de enterramento. A sua arquitectura e algum espólio têm permitido interpretações contraditórias, pelo menos ao nível da possível origem dos construtores daquele túmulo (CARDOSO, 1995; 1999/2000; Silva E GoMES, 1992; ArRUdA, 1993; 1994).

Necrópoles são também as de Meijão e Tanchoal, em Alpiarça, cuja datação do Bronze Final pode recentemente ser aferida através de datações de radio carbono (VILAÇA et alii, 1999). No Cabeço da Bruxa, os dados das escavações recentes indiciam que se está também perante uma necrópole (KALB e HöcK, 1980; 1983).

Os conjuntos materiais que definem o final da Idade do Bronze no estuário do Tejo e regiões anexas são, fundamentalmente, cerâmicos e metálicos.

As cerâmicas decoradas com retícula brunida, também conhecidas por "tipo Lapa do Fumo", são habitualmente consideradas como definidoras desta etapa da Idade do Bronze, e a sua presença costuma servir para a inserção de um qualquer sítio neste momento. Na região em análise, esta decoração, que ocorre exclusivamente nas superfícies externas dos vasos, está documentada quer em povoados quer em grutas ou monumentos funerários, como por exemplo: Moinhos da Atalaia, Grutas do Poço Velho, Gruta da Ponte da Lage, Portucheira, Castelo dos Mouros, Cabeço dos Moinhos, Abrigo I das Bocas, Pragança, Gruta do Correio Mor, Gruta do Vimieiro, Cova da Moura, Fojo dos Morcegos, tholos do Monge, tholos do Barro, Roça do Casal do Meio, Lapa do Fumo, Alpiarça. A restante cerâmica é também maioritariamente de cozedura redutora, podendo apresentar as superfícies polidas ou simplesmente alisadas. Morfologicamente, as taças carenadas são habituais, mas outras formas, como as "urnas", os potes, os grandes vasos de armazenamento, fazem também parte do conteúdo dos inventários. Em alguns vasos, concretamente os pequenos potes, ou panelas, pode observar-se uma decoração incisa sobre o bordo - são os chamados bordos denteados. Nesta mesma forma, um alisamento mal cuidado da superfície externa produz o que se costuma designar por "paredes cepilladas". Estes 
tipos formais e decorativos são comuns à totalidade dos sítios do Bronze Final estremenho, nomeadamente: Alto das Bocas, Pragança, Columbeira, Quinta do Almaraz, Quinta do Marcelo, Penedo do Lexim, Cabeço dos Moinhos, Castelo dos Mouros, Moinho do Raposo.

Os artefactos metálicos do Bronze Final da Estremadura portuguesa são, fundamentalmente, provenientes dos famosos "depósitos votivos" ou "depósitos de sucata", ou resultaram de achados fortuitos. A este facto pode talvez ser assacada a responsabilidade da preponderância de armas e de objectos de adorno sobre os utensílios que se verifica neste período e nesta região. Com efeito, entre os treze artefactos do depósito dos Fiéis de Deus (Bombarral), por exemplo, reconheceuse um único machado para os seis braceletes, um punhal e uma ponta de lança (Melo, 2000). Mas convém notar que mesmo nos depósitos os objectos de adorno apresentam escassa diversidade, resumindo-se, quase exclusivamente, a braceletes. Abundantes nos depósitos, estão escassamente representados em contexto de habitat, conhecendo-se os seis de Cabeço dos Moinhos, Mafra (VICENTE e ANDRADE, 1971), havendo ainda referência à descoberta de um fragmento na Quinta do Marcelo em Almada, (MElo, 2000). Nas necrópoles de Alpiarça, os braceletes são numerosos (MARQUES, 1972; MARQUES e ANDRADE, 1974).

Curiosamente, as fíbulas são muito raras nos depósitos (MElo, 2000), mas a sua presença é significativa nos povoados do estuário.

Na margem esquerda, no concelho de Almada, tanto a Quinta do Almaraz como a Quinta do Marcelo forneceram fíbulas de dupla mola em abundância (BARROS, 2000) e, na margem direita, este mesmo tipo de fíbula registou-se no Alto das Bocas (CARREIRA, 1994).

Também a Sul do Tejo, mas já próximo do estuário do Sado, uma fíbula de enrolamento no arco foi recolhida no monumento da Roça do Casal do Meio, em Sesimbra (SPINDLER et alii, 1973-74), monumento que forneceu ainda duas pinças (Ibidem), artefactos que não sendo de adorno, não cabem também na categoria de utensílios em sentido estrito.

Uma fíbula de cotovelo foi encontrada no Alto das Bocas, em Rio Maior (CARREIRA, 1994), juntando-se assim a que era conhecida da Quinta do Marcelo (BARROS, 2000).

Objecto de adorno é também o famoso colar de ouro do Casal de Santo Amaro encontrado em Sintra, no século XIX (VAsconcellos, 1896). É proveniente de uma sepultura de inumação e está decorado com motivos geométricos. 
As armas incluem espadas, lanças, punhais e pontas de seta, estando as quatro categorias distribuídas de forma não uniforme na Estremadura.

As primeiras são raras. No depósito de Fiéis de Deus registaramse um exemplar completo e dois fragmentos de lâmina, muito possivelmente, pertencentes a uma única espada (Melo, 2000). Se o exemplar inteiro permite, sem margem para dúvida, a sua integração no "tipo Vénat", a classificação dos dois fragmentos num qualquer tipo preciso torna-se praticamente impossível. Contudo, a semelhança que se verifica em todas as lâminas deste depósito permite talvez admitir um mesmo tipo comum, que, a avaliar pela peça completa, seria um híbrido entre uma espada de "tipo Huelva" (pela lâmina) e uma de "tipo Vénat" (pela empunhadura). Uma espada de "tipo Huelva" foi dragada das águas do estuário do Tejo (SILva e Gomes, 1992). Ainda de "tipo Huelva" parece ser o fragmento da Columbeira (COFFYN, 1985).

As pontas de lança são conhecidas nos povoados da Estremadura, como a Ota, Pragança, Alto das Bocas e Columbeira e no depósito dos Fiéis de Deus. Recentemente, foi recolhido um exemplar no Penedo do Lexim (Mafra) (SousA et alii, 2004). Estas pontas de lança da Estremadura distribuem-se pelos "tipos Vénat", "derivado de Vénat" e Pragança.

Os punhais são abundantes nos depósitos e nos sítios de habitat. Os de "tipo Porto de Mós" foram recolhidos na Columbeira, Pragança, Moinho do Raposo, Alto do Castelo e Lapa do Fumo. O punhal do depósito dos Fiéis de Deus, de folha triangular simples e lingueta bipartida, subtriangular e com dois orifícios para rebitagem, apresenta características tipológicas arcaicas (MELO, 2000), concretamente dos inícios do Bronze Pleno ou transição do Calcolítico para a Idade do Bronze, cabendo, dificilmente, nos parâmetros cronológicos que nos ocupam.

As pontas de seta de pedúnculo e aletas estão completamente ausentes dos depósitos, mas encontraram-se em Pragança e no Alto das Bocas (CARREIRA, 1994).

Entre os utensílios, os machados de talão unifacial do grupo 36 de Monteagudo e de alvado foram encontrados nos povoados de Ota (Alenquer), Cabeço dos Moinhos e Penedo do Lexim (Mafra), Pragança (Cadaval), Columbeira e Cesareda (Óbidos), Monte de S. Martinho (Rio Maior), Gruta da Cova da Moura, Torres Vedras (Coffyn, 1985) bem como no depósito de Fiéis de Deus (Melo, 2000).

As foices de talão de "tipo Rocanes", cujo molde foi reconhecido no sítio epónimo do concelho de Sintra, conhecem-se em Pragança, 
S. Martinho e Pedreiras (Sesimbra). Também no Alto das Bocas foi recolhida uma foice que sendo de alvado, tem um gume rectilíneo que difere do côncavo habitual nestes tipos, aproximando-se do "tipo Rocanes" (CARREIRA, 1994).

Até há pouco tempo, os tranchets eram praticamente desconhecidos na Estremadura. O exemplar da Quinta do Marcelo, em Almada, recentemente descoberto (BARROS, 2000), veio juntar-se ao que era já conhecido do Alto das Bocas (CARREIRA, 1994).

Quanto às argolas, muito abundantes na Estremadura portuguesa quer em contexto habitacional quer nos depósitos votivos ou de fundidor, parece existir alguma unanimidade em relação ao facto de se tratar de elementos de arnês. Na Estremadura encontraram-se no Alto das Bocas, Pragança, Columbeira, Tapada da Ajuda e no tholos do Barro.

Entre os artefactos metálicos encontrados na Estremadura, devem ainda destacar-se as facas. Na Quinta do Marcelo, foram recolhidos exemplares destes utensílios. A maioria é de bronze, mas o sítio ofereceu também dois exemplares de ferro com rebites de bronze (BARROS, 2000).

Uma última palavra sobre os artefactos metálicos de Bronze da Estremadura impõe-se ainda. As análises efectuadas à composição química do conjunto dos materiais recolhidos em Fiéis de Deus mostraram que se trata de ligas binárias de cobre e de estanho (MELo, 2000), situação que foi igualmente verificada para a ponta de lança do Lexim (SousA et alii, 2004) e que é, aliás, comum à restante metalurgia da Idade do Bronze do território actualmente português (SOARES et alii, 1996; VILAÇA, 1997) e mesmo de grande parte da restante Península Ibérica (RovIRA, 1995).

Ao conjunto de materiais encontrados na região do Baixo Tejo e datáveis do Bronze Final podemos ainda acrescentar as contas de colar de âmbar encontradas na Quinta do Marcelo (Almada), cuja origem não pode, contudo, ser ainda determinada (BARROS, 2000).

As condições concretas em que se formou o actual conhecimento sobre a realidade do Bronze Final estremenho, já atrás referidas, são responsáveis pela ausência de outros dados, nomeadamente os que se prendem com aspectos relacionados com a dieta alimentar. A ausência de estudos faunísticos, carpológicos, ou palinológicos, nesta região e neste período, não permite conhecer que espécies eram cultivadas, ou que animais eram consumidos. 


\subsubsection{A Idade do Ferro}

O início da Idade do Ferro no estuário do Tejo e áreas adjacentes foi marcado pela chegada e instalação de populações orientais à região. Com efeito, são vários os sítios, quer na foz quer no extremo interno do estuário, que evidenciam a extrema importância da componente alógena.

Sítios como Lisboa, Almaraz e Santarém constituem-se enquanto paradigmas de uma situação em que novas tecnologias e outros hábitos alimentares exteriores ao território actualmente português são adoptadas pelas populações autóctones e usadas pelos grupos exógenos que, admitimos, se instalaram na foz do Tejo em torno a 800 a. C.

As cerâmicas a torno irromperam a partir do final do século VIII a. C., e com elas novas morfologias e técnicas decorativas. Há dados que comprovam que estas novidades tecnológicas foram acompanhadas pela introdução de outros hábitos alimentares e que a paisagem sofre modificações significativas.

Ao nível da estratégia de povoamento, dominam os sítios alcantilados, com amplo domínio visual e boas condições naturais de defesa. Povoados como Almaraz, na foz do estuário, e Santarém, no extremo do mesmo, mantêm-se ocupados, mas a verdade é que a larga maioria dos sítios com ocupação do Bronze Final e anteriormente referenciados são abandonados no início da Idade do Ferro, mas alguns deles voltam a ser ocupados a partir dos finais do século VI a. C.

Nos inventários dos materiais recolhidos, as cerâmicas manuais continuam presentes em grandes quantidades, permanecendo inalteradas formas e técnicas decorativas e de acabamento típicas do momento imediatamente anterior: o Bronze Final. As taças carenadas, cozidas em ambiente redutor, com paredes de escassa espessura e com as superfícies polidas ou mesmo brunidas mantêm-se, muitas das quais possuindo o típico ônfalo. Os potes e/ou panelas encontram-se em grandes quantidades, e, muitas vezes, apresentam as paredes cepilladas e os bordos denteados. Ainda de fabrico manual, mas já claramente sidéricos, são os chamados vasos "à chardon”, cuja presença em Santarém é significativa (ARRUdA, 1999/2000).

Mas as cerâmicas a torno integraram então os conjuntos cerâmicos, e as superfícies de alguns vasos, como os pratos, as taças e os unguentários, apresentam espessos e bem aderentes engobes vermelhos, polidos ao torno. Na Sé de Lisboa, na Alcáçova de Santarém e na 
Quinta do Almaraz a cerâmica de engobe vermelho é abundante entre o século VIII e o século VI a. C. (ARRUDA, 1999/2000; BARros et alii, 1993).

Os grandes vasos de armazenamento de tipo pithoi, com duas ou quatro asas e pintados na superfície externa com bandas e linhas vermelhas e negras, são comuns a partir do século VII a. C., em Santarém e Lisboa (ARRUDA, 1999/2000), sítios em que as chamadas "urnas" Cruz del Negro, também pintadas em bandas, se encontram igualmente presentes, ainda que em menor número (Ibidem).

Os produtos alimentares produzidos na região gaditana chegaram ao estuário do Tejo envasados em ânforas da série 10 de Joan Ramón (Ibidem). De Santarém e Lisboa são provenientes bordos que podemos integrar nos tipos 10.1.1.1. e 10.1.2.1. (Ibidem), as primeiras do século VIII e as segundas mais tardias, datadas entre o século VII e o século VI a. C. Em Almaraz, as ânforas R1 são, na totalidade, integráveis no segundo tipo, pertencendo, portanto, a uma fase mais avançada desta I Idade do Ferro Orientalizante.

Típicas deste momento inicial da Idade do Ferro são as chamadas cerâmicas cinzentas, de paredes polidas ao torno, cuja forma dominante é o prato ou taça de bordo engrossado no interior. As taças carenadas, os pratos de bordo largo, os potes e outras formas são também habituais e frequentes em Lisboa, Santarém (Ibidem) ou Almaraz (BARRos, 2000).

Para além da introdução do torno, parece certo que é também às populações orientais provenientes da região do Estreito de Gibraltar que devemos assacar a responsabilidade da introdução, na área em estudo, da técnica da pasta vítrea, presente em Santarém sob a forma de contas de colar azuis ou oculadas (ARRUDA, 1999/2000), e em Almaraz, onde, para além das contas de colar, foram recolhidos fragmentos de pequenos unguentários (BARRos, 2000). E o pequeno vaso de alabastro do sítio almadense é mais um dado a juntar à panóplia de importações orientais da área do estuário do Tejo (Ibidem).

Os trabalhos arqueológicos levados a efeito na Alcáçova de Santarém (ARRUDA, 1993; ARRUDA, 1999/2000) permitiram recolher matéria orgânica que possibilitou a realização de análises de radiocarbono. Tais análises, que colocam o início da ocupação sidérica do sítio entre os finais do século X e os inícios do século VIII a. C., deram mais consistência aos dados que podiam já inferir-se do estudo tipológico do espólio cerâmico: a chegada de populações orientais à foz do Tejo ocorreu num momento bastante recuado, aproximadamente uma geração 
depois da instalação na região gaditana de grupos de colonizadores provenientes da fachada sírio-palestniana.

O estudo da fauna de Santarém, realizado por Simon David, permitiu identificar galináceos nestas mesmas fases antigas da ocupação do sítio, o que comprova a introdução e o consumo de espécies animais, comuns no Próximo Oriente, mas desconhecidas, até então, no território actualmente português. Mas, ficou também comprovado a extrema importância da actividade cinegética, consubstanciada pela presença massiva de cervídeos. Naturalmente que os ovicaprinos e, sobretudo os bovídeos, contribuíram também, e de forma significativa, para a dieta alimentar das populações que ocuparam o planalto escalabitano e os suídeos estão igualmente presentes tanto na versão doméstica como na selvagem.

Os perfis palinológicos obtidos no Paul dos Patudos, em Alpiarça (LEUWAARDEN e JANSEN, 1985), mostram, também em torno a esta época, um considerável alargamento da área cultivável e um recuo das áreas arborizadas, do que pode deduzir-se um aumento demográfico. Estes mesmos estudos evidenciaram a presença de poléns de vitis, não sendo impossível relacionar também este cultivo com a chegada de populações orientais ao estuário do Tejo.

Os estudos carpológicos realizados pela equipa do CIPA sobre as sementes recolhidas, em grandes quantidades, na Alcáçova de Santarém, tornaram clara a importância de um cultivo cerealífero dominado pela cevada vestida, mas também pelo trigo, ainda que a presença de leguminosas, concretamente da fava, evidencie (ARRUDA, 2003) a prática hortícola.

A ocupação de Santarém, Lisboa e Almaraz prolongou-se, sem interrupção, até à actualidade, nos primeiros dois casos, e, no terceiro, até à época romana. A componente orientalizante permanece imutável durante toda a primeira metade do $10^{\circ}$ milénio a. C. e o que muda é basicamente a proporção existente entre a cerâmica manual e a cerâmica a torno, com a primeira a diminuir e a última a aumentar (ARRUDA, 1999/2000). Ainda assim, em Santarém pode notar-se uma evolução formal no perfil dos pithoi (Ibidem), e a introdução de novas técnicas decorativas, de origem aparentemente peninsular (ARRUDA, no prelo). É o caso das cerâmicas de tipo Medellín, com traços pintados de branco que desenham um reticulado, mais ou menos, complexo.

A partir dos finais do século VI a. C., alguns dos povoados do Bronze Final que tinham sido abandonados no início da Idade do Ferro 
voltaram a ser reocupados. Moinhos da Atalaia, na Amadora, Santa Eufémia e Castelo dos Mouros em Sintra, ou Cabeço dos Moinhos e Serra do Socorro, em Mafra contam-se entre os exemplos desta situação.

A ocupação da Idade do Ferro dos Moinhos da Atalaia está consubstanciada em cerâmicas de matriz mediterrânea, como as cinzentas finas polidas, as de pastas alaranjadas e as ânforas, de tipo Mañá Pascoal A4, e ainda em fíbulas anulares hispânicas (PINTO e PARREIRA, 1978). O aparecimento, no decorrer das escavações de S. Pedro de Canaferrim-Castelo dos Mouros, de um fragmento de cerâmica ática e de uma parede de um vaso de pasta vítrea azul decorado com linhas amarelas (informação de Catarina Coelho e Teresa Simões, a quem agradecemos) pode testemunhar fenómeno idêntico. Em Santa Eufémia, as características formais dos materiais atribuíveis à Idade do Ferro apontam também para uma cronologia dos séculos VI e V a. C., como é o caso das ânforas de tipo Mañá Pascoal A4 (MARQues, 1982-83). No depósito do Museu Municipal de Mafra e no Museu de Torres Vedras, existem abundantes testemunhos de uma ocupação sidérica da Serra do Socorro, que igualmente não parece, contudo, recuar para trás do século VI a. C. Para além das recolhas antigas de Prescott Vicente e Gil Miguéis de Andrade no Cabeço dos Moinhos (1971), o Gabinete de Arqueologia da Câmara Municipal de Mafra recolheu, recentemente, um conjunto de materiais da Idade do Bronze Final e da II Idade de Ferro, o que configura idêntica situação.

Para além desta reocupação de alguns dos sítios do Bronze Final, parece ter-se verificado, neste mesmo momento (final do século VI a. C.), a fundação de outros, de que Freiria (Cascais) se assume como um bom exemplo (CARDOSO e ENCARNAÇÃO, 1999).

\section{Entre o Bronze e o Ferro ao longo do Tejo: rupturas e continui- dades}

Pensamos que os dados que atrás apresentámos sobre o estuário e o curso médio do Tejo referentes à ocupação humana das suas margens (sobretudo a direita), durante o Bronze Final, evidencia, de facto, a existência de um "corredor estremenho beirão" que ligou as duas áreas. Que esse "corredor" funcionou, quase exclusivamente, pela margem Norte, parece também ser de admitir, tendo em consideração os mesmos dados. 
Não só os materiais arqueológicos, quer cerâmicos quer metálicos, apresentam tipologias e funcionalidades muito idênticas, como também a implantação topográfica dos locais ocupados mostra similitudes várias, ainda que os chamados "casais agrícolas", existentes no estuário, não pareçam existir no médio Tejo, se exceptuarmos o caso das "cabanas" de S. Domingos, em Castelo Branco (CARDoso et alii, 1998), cuja funcionalidade poderá, no entanto, ser discutida (VILAÇA, 2000a: 176 e nota 21). Poderia dizer-se que se a escolha de lugares com boas condições naturais de defesa e bom domínio visual nas duas regiões, durante o Bronze Final, foi uma realidade (ainda que no estuário de forma não exclusiva, mas maioritária), as áreas ocupadas não seriam comparáveis, dada a reduzida dimensão dos povoados do médio Tejo, quer em termos absolutos quer quando comparadas com os amplos povoados do estuário. Contudo, e ainda que as plataformas onde a ocupação destes últimos atinjam, efectivamente, superfícies vastas (que podem chegar aos 3 hectares), não é seguro, dada a ausência de trabalhos arqueológicos, que elas estivessem ocupadas integralmente. E se em ambas as áreas a existência de linhas de muralhas envolvendo os povoados é uma realidade, também é verdade que, quer no estuário quer no médio Tejo, a cronologia destas estruturas defensivas pode não ser reportável, na totalidade, ao Bronze Final.

Por outro lado, cremos que os dados da cultura material apresentados nos capítulos anteriores são muito elucidativos sobre a profunda relação existente entre as duas áreas estudadas, parecendo-nos dispensável voltar a fazer referência individual aos tipos cerâmicos e às suas decorações, bem como à tipologia dos artefactos metálicos e até das ligas de que são constituídos. No entanto, talvez faça algum sentido, nesta "conclusão", chamar à colação o facto da existência de utensílios de ferro em contexto do Bronze Final em ambas as áreas.

As datações de radiocarbono que foram sendo obtidas nos últimos anos para as ocupações do final do II/inícios do I milénio a. C. ao longo do Tejo evidenciam também uma sincronia quase absoluta.

Curiosamente, os dados parecem também indicar que o "corredor" que as ligava funcionou exclusivamente pela margem norte do Tejo, ainda que possa admitir-se que o défice de investigação possa ser responsável pela ausência de dados deste período na margem esquerda do rio. Com efeito, apenas no estuário e na região de Alpiarça a ocupação humana está demonstrada neste momento, tal como, aliás, durante o início da Idade do Ferro. 
A aparente descontinuidade geográfica das duas regiões, em termos de ocupação humana durante o Bronze Final, tem vindo a ser colmatada pelos trabalhos de investigação desenvolvidos no Alto Ribatejo, que têm fornecido contornos mais nítidos à ligação existente entre ambas e ainda à localização a norte do rio do que pode ser chamado "corredor estremenho/beirão".

Com efeito, sítios do Bronze Final são já conhecidos em Tomar, Abrantes, Mação e Sardoal, com espólios idênticos aos verificados quer a montante quer a jusante, concretamente a cerâmica de "ornatos brunidos" e a cerâmica cepillada. Tal como no estuário, a ocupação ocorre tanto em povoados de altura como em "casais agrícolas". Dos primeiros são exemplo a Fortaleza de Abrantes (PEREIRA, 1987), o Cabeço das Mós, no Sardoal, o Castelo Velho de Caratão, em Mação (FÉLIX, 1997). Os pequenos povoados de vale, ocupando encostas suaves, como a Quinta da Pedreira (Ibidem) e Amoreira (CRUZ, 1997), em Abrantes, e Montalvo e Alcobre, em Constância constituem bons exemplos do segundo tipo. No entanto, e uma vez mais como no estuário, a sincronia destes dois tipos de ocupação está ainda por verificar nesta área, não havendo dados que permitam saber se ambas as modalidades de povoamento são efectivamente coevas ou se a primeira se sucedeu à segunda.

A análise das práticas funerárias da transição Bronze/Ferro, aspecto que não nos foi possível explorar neste texto, é um outro campo que merece reflexão futura, tendo presentes as materialidades conhecidas ao longo do Tejo. Para além da Roça do Casal do Meio e de Alpiarça (Meijão, Tanchoal e Cabeço da Bruxa), que evidenciaram a contemporaneidade de práticas conceptualmente não só distintas como opostas - a inumação e a incineração, a monumentalidade e a invisibilidade - há que ter presente as singulares estruturas de São Domingos e deverão ainda ser revistos, procurando-se recuperar, até onde for possível, os respectivos contextos deposicionais, os casos de Santo Amaro (Sintra), Almoster, Quinta da Alorna (Almeirim), Salvaterra e Abrunheira (Portalegre). Outras situações há pelo território espanhol adentro. A linha do Tejo constituiu, sem dúvida, do mundo nordestino ao Atlântico, um importante marcador na assimilação de práticas crematórias, mas, pela mesma altura, outros contextos geográficos e culturais estranhos ao Tejo adoptaram práticas similares. Uns e outros só ganharão se vistos em conjunto.

Poderia parecer que, com a chegada das populações orientais ao ocidente peninsular, a profundidade das relações existentes durante o 
Bronze Final entre o estuário do Tejo e o seu curso médio ter-se-ia perdido. Com efeito, e como foi já referido, a Idade do Ferro no médio Tejo é praticamente desconhecida. Os dados não abundam, a sua qualidade é discutível, e a sua cronologia mais específica também. Esta situação contrasta de forma clara com o que é conhecido na região estuariana, região que regista, neste momento, uma ocupação humana de forte expressão, além de marcada por um profundo orientalismo.

Mas se parece indiscutível a escassa presença de elementos sidéricos, orientalizantes ou outros, no médio Tejo, a verdade é que a realidade material do estuário e da Extremadura espanhola, durante a Idade do Ferro, é muito próxima. Esta proximidade, materializada nomeadamente pela presença na Alcáçova de Santarém de cerâmicas de tipo Medellín (ARRUDA, no prelo) permite pensar que o processo de orientalização da Estremadura espanhola, bem como, aliás do Alentejo Central, se desenvolveu através do Tejo e não do Guadiana, como sempre tinha sido defendido. Tal proposta (Ibidem), que recuperou uma outra de D. Manuel Pellicer Catállan (2000), teve também por base os dados cronométricos e os espólios da Idade do Ferro do litoral português, bem como as condições específicas de navegabilidade do Tejo, do Guadiana e do Atlântico. Mas assentou, também e sobretudo, na descoberta, no médio Tejo, do sítio da Cachouça (VILAÇA e BASílio, 2000; VILAÇA, no prelo b).

A matriz orientalizante do espólio sidérico deste povoado só pode ser compreendida através de relações mantidas com o litoral, concretamente com o estuário do rio, área em que, como vimos, o orientalismo está fortemente impresso em quase todas as vertentes da ocupação humana a partir de circa de 800 a. C.

Localizado entre duas regiões fortemente orientalizadas (a Estremadura portuguesa e a espanhola), a Cachouça parece corresponder a um "enclave" e ter representado o papel de um gateway entre dois pólos.

Mas os dados em curso de investigação por Paulo Félix em Abrantes e no Sardoal, área onde a ocupação sidérica está também registada, poderá trazer novos elementos para compreendermos a Idade do Ferro ao longo do Tejo.

Descobertas recentes em Toledo, a que se devem juntar outras mais antigas, vêm, na nossa perspectiva, dar maior consistência à hipótese de uma orientalização do interior peninsular através de um percurso Este/Oeste em detrimento do tradicional Sul/Norte, e assim dar relevo, 
neste processo, à Cachouça e outros eventuais sítios sidéricos do médio Tejo. A tumulação de El Carpio (Belvís de la Jara, Toledo), na zona onde as águas do Gévalo se juntam às do Tejo, e atribuível à transição Bronze/Ferro, tinha já revelado uma evidente hibridez cultural, de fundo indígena, a que se juntaram elementos orientalizantes (PEREIRA SiESo e AlVARO, 1986). E agora, sobre a margem direita do rio, identificaram-se no povoado de Cerro de la Mesa (Alcolea del Tajo, Toledo - Castilla la Mancha), níveis que correspondem à I Idade do Ferro orientalizante, datados genericamente do século VI a. C. (ORTEGA Blanco e Valle GutiérRez, 2004). Entre o espólio destacam-se os pythoi pintados em bandas (Ibidem, lám. III), de tipologia e esquema decorativo idênticos aos recuperados na Alcáçova de Santarém em contextos dos séculos VII e VI a. C. Mais importante, parece ser a descoberta de um altar em forma de lingote cipriota ou pele de boi estendida ("figura", aliás, já presente sob a forma de placas cerâmicas naquela sepultura), que apresenta semelhanças com o de Cancho Roano, apesar deste último poder ser datado de um momento mais tardio, concretamente o século $\mathrm{V}$ a. $\mathrm{C}$.

Esta presença oriental, tão interior e setentrional, mas ainda na margem direita do Tejo, pelo menos no que diz respeito ao povoado de Cerro de la Mesa, permite, com efeito, traçar com mais nitidez as linhas de um quadro em que o Tejo funcionou como a grande estrada aquática, através da qual as influências orientais penetraram no centro/interior peninsular.

\section{BIBLIOGRAFIA}

Antunes, M. T. (1992) - Povoados do Bronze Final da Beira Baixa - Alegrios, Moreirinha e Monte do Frade: elementos arqueozoológicos. Conimbriga. Coimbra, XXXI, p. 31-39.

Arruda, A. M. (1993a) - A Idade do Ferro do Centro/Sul. In História de Portugal. Amadora: Ediclube, vol. 2, p. 45-68.

Arruda, A. M. (1993b) - A ocupação da Idade do Ferro da Alcáçova de Santarém no contexto da expansão fenícia para a fachada atlântica peninsular. Estudos Orientais (Actas do Encontro "Os fenícios no território português") Lisboa. 4: 193214.

Arruda, A. M. (1994) - A Península de Lisboa entre o Norte atlântico e o Oriente mediterrânico. In Lisboa Subterrânea. Lisboa. p. 52-57. 
Arruda, A. M. (1999-2000) - Los fenícios en Portugal: Fenícios y mundo indígena en el centro y sur de Portugal. Barcelona: Cuadernos de Estudios Mediterráneos, 5-6.

ArrudA, A. M. (2003) - Contributo da colonização fenícia para a domesticação da terra portuguesa. In Ecohistoria del paisaje agrario - la agricultura fenício-púnica en el mediterráneo. Valência: Universidad, 205-217.

ArrudA, A. M. (no prelo) - Orientalizante e Pós-orientalizante no sudoeste peninsular: geografias e cronologias. In Actas do Congreso de Protohistoria del Mediterráneo Occidental. Mérida. Maio de 2003.

Barbosa, E. 1956 - O Castro da Ota. O Arqueólogo Português. Lisboa. Série 2, n. ${ }^{\circ} 3$, p. 117-124.

BARros, L. (2000) - O fim do bronze e a Idade do Ferro no território de Almada. Dissertação de mestrado em arqueologia. Lisboa. Faculdade de Letras/Universidade de Lisboa (policopiada).

Barros, L. e EsPírito SANTO, P. (1991) - Quinta do Percevejo - Almada. Uma intervenção de emergência. In Actas da IV Jornadas da Associação dos Arqueólogos Portugueses. Lisboa. p. 333-342

Barros, L; Cardoso, J. L. e Sabrosa, A. (1993) - Fenícios na margem Sul do Tejo, (Actas do Colóquio “Os Fenícios no território português”, 1992). Estudos Orientais. Lisboa. IV, p. 143-181.

Batata, C., Gaspar, F. e Batista, A. (1999) - O ineditismo do $1 .^{\circ}$ milénio a. C. da bacia hidrográfica do rio Zêzere no contexto da arqueologia proto-histórica nacional. II Congreso de Arqueología Peninsular. Tomo III - Primer Milenio y Metodología. Universidad de Alcalá, p. 25-35.

Bettencourt, A. M. S. e SAnches, M. J. (1998) - Algumas questões sobre a Idade do Bronze do Norte de Portugal. In Fábregas Valcarce, R. (Ed.), A Idade do Bronce en Galicia: novas perspectivas. A Coruña. Cadernos do Seminario de Sargadelos, 77, p. 13-45.

BÜBNER, T (1996) - A cerâmica de ornatos brunidos em Portugal. In Alarcão, J. (ed.) De Ulisses a Viriato. Lisboa: Museu Nacional de Arqueologia. p. 66-72.

Calado, M.; Barradas, M. P. e Mataloto, R. (1999) - Povoamento Proto-histórico no Alentejo Central. Revista de Guimarães, Guimarães. Vol. Especial [Actas do Congresso de Proto-História Europeia, vol. 1, p. 363-386].

CARdoso, G. e EncARnAÇão, J. (1999) - Notas sobre a ocupação proto-histórica na Villa Romana de Freiria. Revista de Guimarães, Guimarães. Vol. Especial [Actas do Congresso de Proto-História Europeia, vol. 2, p. 741-757].

CArdoso, J. L. (1990) - A presença oriental no povoamento da I Idade do Ferro na região ribeirinha do estuário do Tejo. Estudos Orientais 1 (Actas do Encontro Presenças Orientalizantes em Portugal. Da Pré-História ao Período romano). Lisboa $119-133$.

CARdoso, J. L. (1994) - Lisboa. Do paleolítico ao romano. Investigação arqueológica na área de Lisboa: os últimos 10 anos. Al-madan 6: 59-74.

CArdoso, J. L. (1995) - O Bronze Final e a Idade do Ferro na região de Lisboa: um ensaio. Conimbriga. Coimbra. 34, p. 33-74. 
Cardoso, J. L. (1997-1998) - O povoado do Bronze Final do Castelo dos Mouros (Sintra). Estudos Arqueológicos de Oeiras. Oeiras, 6, p. 169-187.

Cardoso, J. L. (1999-2000) - Aspectos do povoamento da Baixa Estremadura no decurso da Idade do Bronze. Estudos Arqueológicos de Oeiras. Oeiras. 7, p. 355-413. Cardoso, J. L. e Cardoso, G. (1996) - O povoado do Bronze final do Alto das Cabeças (Leião, Oeiras). Estudos Arqueológicos de Oeiras. Oeiras. 6, p. 351-359.

Cardoso, J. L., Caninas, J. C. e Henriques, F. (1998) - Duas cabanas circulares da Idade do Bronze Final do Monte de São Domingos (Castelo Branco). Estudos Pré-históricos. [Colóquio “A Pré-história na Beira Interior”]. Viseu. 6, p. 325-345].

CArdoso, J. L. Leitão, Veiga, North, Norton (1999) - A cerâmica de ornatos brunidos da Gruta do Correio Mor. (Loures). Estudos Arqueológicos de Oeiras. 7, p. $155-167$.

CARreirA, J. L. (1994) - Pré-História recente do Abrigo Grande das Bocas (Rio Maior). Trabalhos de Arqueologia da EAM. Lisboa. 2, p. 47-134.

Coffyn, A. (1985) - Le Bronze Final Atlantique dans la Péninsule Ibérique. Paris: Diffusion de Boccard.

CuRT, B. e VILAÇA, R. (1995) - The provenience of portuguese archaeological amber artefacts - a case study from Moreirinha (Beira Baixa). Trabalhos de Antropologia e Etnologia. 35(4) [Actas do $1 .{ }^{\circ}$ Congresso de Arqueologia Peninsular, VIII]. Porto, p. 207-219.

FÉLIX, P. (1993) - A região nabantina no final da Pré-história: algumas considerações acerca do estudo do povoamento do $10^{\circ}$ milénio a. C. Boletim Cultural da Câmara Municipal de Tomar. Tomar. 19, p. 239-254.

FÉlIX, P. (1997) - O Final da Idade do Bronze no médio Tejo. Quinta da Pedreira. Notícia de duas campanhas de escavações arqueológicas (1994 e 1996). Al-madan. Almada. 6, p. 33-37.

FÉliX, P. (2000) - O Final da Idade do Bronze no Centro-Oeste Peninsular: a contribuição do Ribatejo Norte. Revista de Guimarães, Guimarães. Vol. Especial [Actas do Congresso de Proto-História Europeia, vol. 2, p. 715-740].

Gamito, T. J. (2002) - As Civilizações da Idade do Ferro em território português nos últimos 100 anos. Arqueologia e História [Arqueologia 2000. Balanço de um Século de Investigação Arqueológica em Portugal]. Lisboa, Associação dos Arqueólogos Portugueses, vol. 54, p. 125-138.

GasPar, J. (1970) - Os portos fluviais do Tejo. Finisterra. Lisboa, vol. V (10), p. 153-204.

Jorge, S. O. (1997) - O Bronze Final no Norte de Portugal: uma história em discussão. In Redentor, A. (Ed.), O $1 .^{\circ}$ milénio a. C. no Noroeste Peninsular; a fachada atlântica e o interior. Bragança, Parque natural de Montezinho, p. 13-22.

Kalb, P. (1980) - O Bronze Atlântico em Portugal. In Actas do Seminário de Arqueologia do Noroeste Peninsular. Guimarães. 1, p. 113-120.

Kalb, P. e HöcK, M., (1980) - Cabeço da Bruxa, Alpiarça (Distrikt Santarém). Vorberich uber die Grabung im Januar und Februar 1979. Madrider Mitteilungen, 21, p. $91-104$.

Kunst, M. (1995) - In Jorge, S. (ed.) A Idade do Bronze em Portugal. Discursos de poder. Lisboa: Instituto Português de Museus, p. 124-125. 
LEUWAARDEN, W. van e JANSEN, C.R. (1985) - A preliminary palynological study of a peat deposits near an oppidum in the lower Tagus valley, Portugal. In Actas da I reunião do quaternário ibérico. Lisboa: Grupo de trabalho para o Estudo do quaternário/Grupo Español de Trabajo del cuaternario. Vol. II, p. 225-235. Madeira, J., Gonçalves, J. L., Raposo, L. Parreira, R., (1972) - Achados da Idade do Bronze no Monte da Pena (Barro. Torres Vedras) - Notícia prévia. O Arqueólogo Português. Lisboa. Série 3, n. ${ }^{\circ}$ 6, p. 207-212.

MARques, G. (1972) - Arqueologia de Alpiarça. As estações representadas no Museu do Instituto de Antropologia do Porto. Trabalhos de Antropologia Dr. Mendes Correa. MARques, G. (1982-83) - Aspectos da Proto-história do território português. II - Povoado de Santa Eufémia (Sintra). Sintria. 1, p. 59-87.

Marques, G. (1994) - A Cultura de Alpiarça. In Pereira, I. (Coord.), Idade do Ferro. Catálogo. Câmara Municipal da Figueira da Foz, Serviços Culturais. Museu, p. 65-69.

MARQUeS, G. e ANDRADE, G. M. (1974) - Aspectos da proto-história do território português 1 - definição e distribuição geográfica da cultura de Alpiarça (Idade do Ferro). In Actas do III Congresso Nacional de Arqueologia: p. 125-148.

Mataloto, R. (1999) - As ocupações Proto-históricas do Castelo do Giraldo (Évora). Revista de Guimarães, Guimarães. Vol. Especial [Actas do Congresso de ProtoHistória Europeia, vol. 1, p. 333-362].

Melo, A. (2000) - Armas, utensílios e esconderijos. Alguns aspectos da metalurgia do Bronze Final: o depósito do Casal dos Fiéis de Deus. Revista Portuguesa de Arqueologia. Lisboa: IPA, 3, n. ${ }^{\circ}$ 1, p. 15-120.

Ortega Blanco, J. e Valle Gutiérrez, M. (2004) - El poblado de la Edad del Hierro del Cerro de la Mesa (Alcolea de Tajo, Toledo). Primeros resultados. Trabajos de Prehistoria. Madrid: 61 (1), p. 175-185.

Pellicer Catalán, M. (2000) - El proceso orientalizante en el occidente ibérico. Huelva Arqueológica. Huelva: Diputación Provincial, 16, p. 90-127.

Pereira Sieso, J. e Alvaro, E. (1986) - Aportes orientalizantes en el valle del Tajo. Revista de Arqueologia. Madrid: año VII, n. ${ }^{\circ} 62$, p. 29-39.

Pereira, M. A. (1971) - Monumentos Históricos do Concelho de Mação. Coimbra. Pereira, M. A. (1988) - Cerâmica do Bronze Final da Fortaleza de Abrantes. In Actas do Simpósio sobre o Bronze Final na Beira interior. Mação (no prelo?).

Pinto, C. e Parreira, R., (1978) - Contribuição para o estudo do Bronze Final e do Ferro Inicial a norte do Estuário do Tejo. In Actas das III Jornadas Arqueológicas. Lisboa: Associação dos Arqueólogos Portugueses, p. 147-163.

RAMÓN TORRES, J. (1995) - Las ánforas fenicio-púnicas del mediterráneo central y occidental, Universitat, Barcelona.

Ribeiro, O. e Lautensach, H. (1988) - Geografia de Portugal. II - O Ritmo Climático e a Paisagem. Lisboa. Edições Sá da Costa.

Rovira Llorens, S. (1995) - Estudio arqueometalúrgico del depósito de la ria de Huelva. In Ritos de paso e puntos de paso. La ria de Huelva en el mundo del Bronce Final Europeo. Madrid: Universidad Complutense, p. 33-55.

RuIz Gálvez, M. (1998) - La Europa Atlántica en la Edad del Bronce. Un viaje a las raices de la Europa Occidental. Barcelona: Critica. 
SennA-Martinez, J. C., (2000) - O problema dos primeiros ferros peninsulares em contextos do Bronze Final da Orla Atlântica: os dados do "Outeiro dos Castelos de Beijós" (Carregal do Sal). Trabalhos de Arqueologia da EAM. Lisboa: Colibri, 6, p. 39-56.

Silva, A. C. F. e Gomes M. V. (1992) - Proto História de Portugal. Lisboa: Universidade Aberta.

Silva, J. C.; BAtista, A. e FÉliX, P. (1999) - Uma foice do Bronze Final provenienete da Quinta do Vale do Zebro (Rio de Moinhos, Abrantes). Estudos Pré-Históricos. Viseu: CEPBA, VII, p. 257-262.

Soares, A. M.; AraúJo, M. F.; Alves, L.; Ferraz, M. T. (1996) - Vestígios metalúrgicos en contextos calcolíticos e da Idade do Bronze no sul de Portugal. In Miscellanea em Homenagem ao Professor Bairrão Oleiro. Lisboa: Colibri. p. 553-579 .

Sousa, A. C.; Valério, P. e AraúJo, F. (2004) - Metalurgia antiga do Penedo do Lexim (Mafra). Calcolítico e Idade do Bronze. Revista Portuguesa de Arqueologia. Lisboa: IPA. 7, n. ${ }^{\circ}$ 2, p. 97-117.

Spindler, K.; Castelo Branco, A.; Zbyszewski, G. e Ferreira, O. V. (1973-74) - Le monument à coupole de l'âge du bronze final de la Roça do Casal do Meio (Calhariz). Comunicações dos Serviços Geológicos de Portugal. Lisboa, 57, p. 91-154 .

Vasconcellos. J. L. (1896) - Xorca de ouro. O Archeologo Portugues. Lisboa. 2, p. 17-24.

Vicente, E. P. e Andrade, G. M. (1971) - A estação arqueológica de Cabeço dos Moinhos. Breve notícia. In Actas do II Congresso Nacional de Arqueologia, Coimbra. 1, p. 223-238.

VILAÇA, R., (1995) - Aspectos do povoamento da Beira Interior (Centro e sul) nos finais da Idade do Bronze. Lisboa: IPPAR.

VILAÇA, R. (1997a) - Metalurgia do Bronze Final da Beira interior: revisão dos dados à luz dos novos resultados. Estudos Pré-históricos. Viseu. CEPBA, 5, p. 123-154.

VILAÇA, R. (1997b) - Uma nova leitura para o Monte do Frade (Penamacor), Conimbriga. XXXVI, Coimbra, p. 27-44.

VILAÇA, R. (2000a) - Registos e leituras da Pré-história Recente e da Proto-história Antiga da Beira Interior. Actas do $3 .^{\circ}$ Congresso de Arqueologia Peninsular, vol. IV. Porto, p. 161-182.

VILAÇA, R. (2000b) - Notas soltas sobre o património arqueológico do Bronze Final da Beira Interior, in Ferreira, M. C. et alii (eds.), Beira Interior. História e Património [Actas das I Jornadas de Património da Beira Interior], Guarda, p. 31-50 .

Vilaça, R., Cruz, D. J. e Gonçalves, A. H. B. (1999) - A Necrópole de Tanchoal dos Patudos / Alpiarça, Santarém). Conimbriga. XXXVII, Coimbra, p. 5-29.

VILAÇA, R. e BAsílio, L. (2000) - Contributo para a caracterização arqueológica da I Idade do Ferro da Beira Interior: cerâmicas a torno da Cachouça (Idanha-a-Nova). Al-madan. Almada. II série, n. ${ }^{\circ}$ 9, p. 39-47.

Vilaça, R.; Montero Ruiz, I.; Alegria, C.; Silva, R. e Almeida, S. O. (2002-2003) - 
Tapada das Argolas (Capinha, Fundão): novos contributos para a sua caracterização. Estudos Pré-históricos. Viseu, CEPBA, 10-11, p. 175-197.

VilaçA, R.; Smith, W. e SANTos, E. (2004) - Plant impressions in Late Bronze / Early Iron Age pottery from Beira Interior (Portugal). Journal of Iberian Archaeology. Porto, ADECAP, vol. 6, p. 181-208.

VILAÇA, R. (2003) - Acerca da existência de ponderais em contextos do Bronze Final / Ferro Inicial no território português, O Arqueólogo Português. Lisboa, Série IV, vol. 21 , p. 245-288.

VILAÇA, R. (no prelo a) - Reflexões em torno da inovação do ferro e das suas pautas comportamentais na Beira Interior. Actas do $1 .{ }^{\circ}$ Congresso de Arqueologia de tràs-os-Montes, Alto Douro e Beira Interior (Meda, 2004).

VILAÇA, R. (no prelo b) - A Cachouça (Idanha-a-Nova, Castelo Branco). Construção e organização de um caso singular de inícios do I milénio AC. IV Congresso de Arqueologia Peninsular (Faro, 2004). 


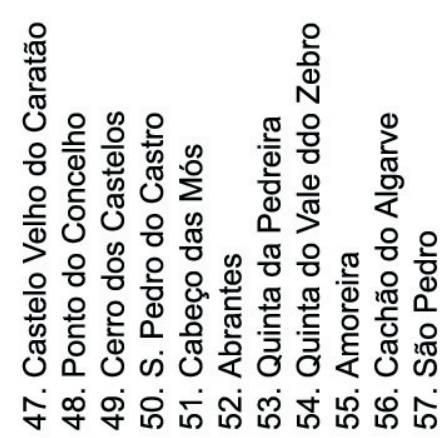

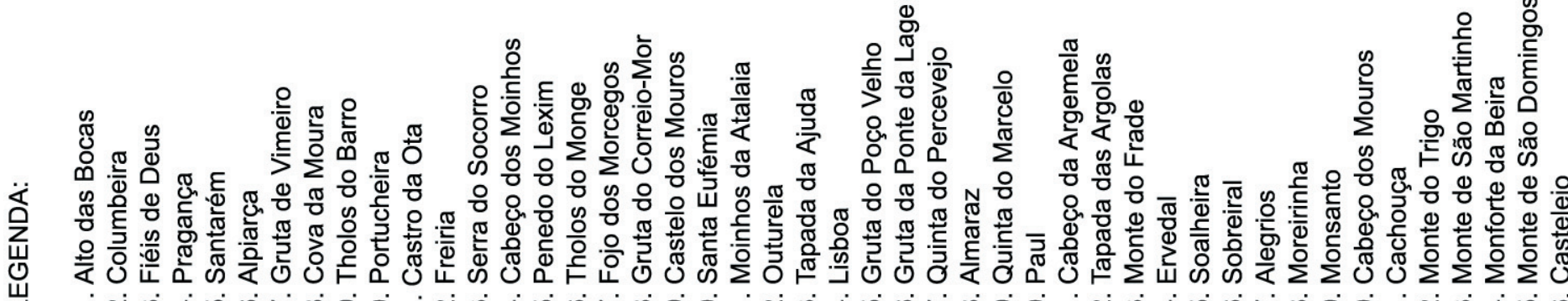

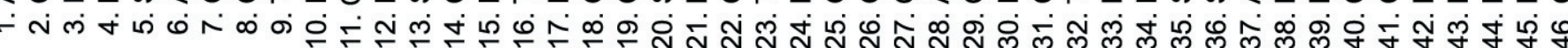

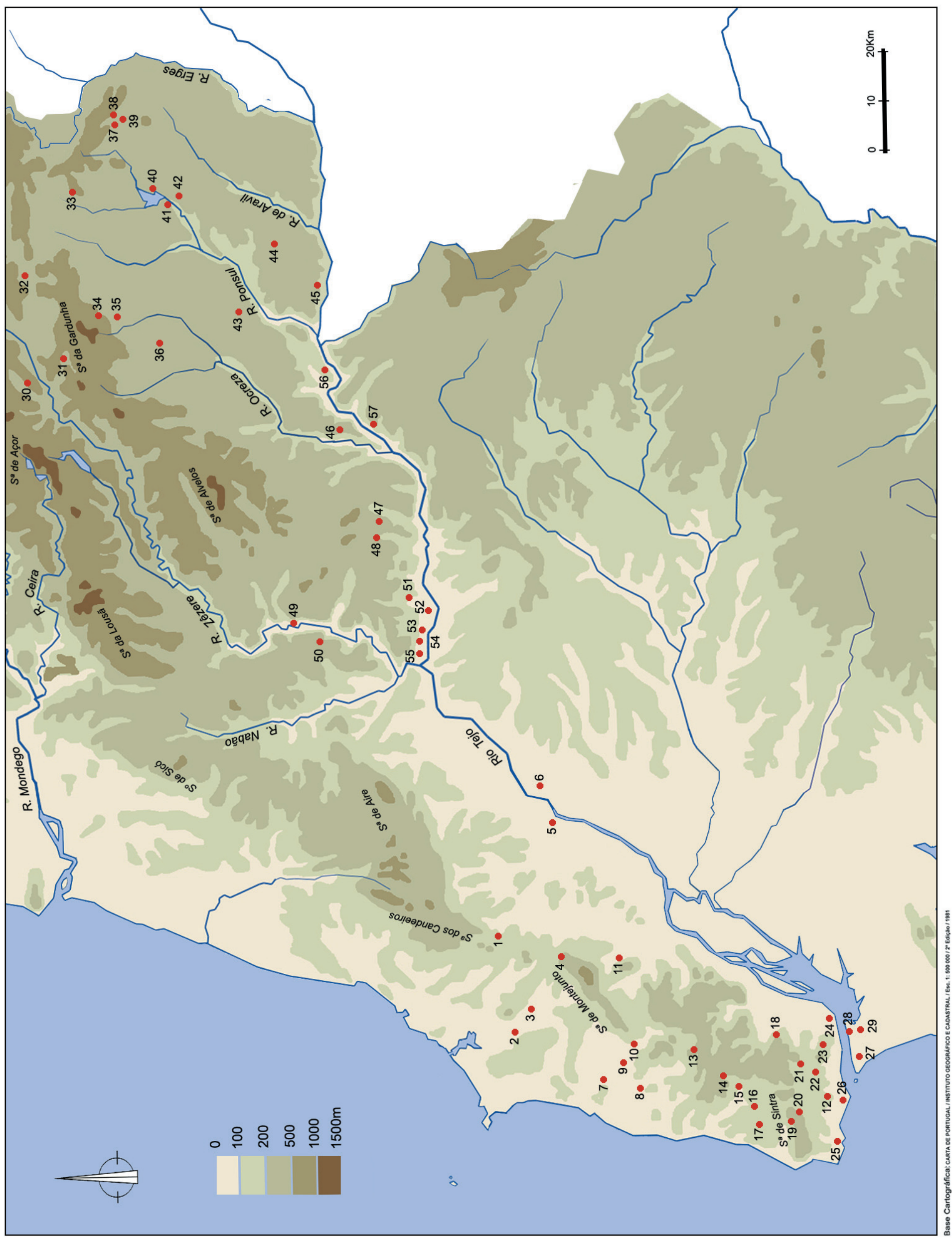

